\title{
UPAYA MENINGKATKAN PRODUKTIVITAS KERJA KARYAWAN PADA PT. PERDANA SAWIT PLANTATION KECAMATAN KETUNGAU TENGAH
}

\author{
Evy Ratnasari \\ Fakultas Ilmu Sosial dan Ilmu Politik Universitas Kapuas
}

\begin{abstract}
Abstrak: Untuk meningkatkan produktivitas kerja karyawan, pimpinan perusahaan sudah memberikan motivasi kepada para karyawan untuk bekerja dengan baik, penuh semangat, dan berdisiplin. Bentuk motivasi yang diberikan dalam berbagai hal seperti memberikan insentif terhadap karyawan yang melakukan pekerjaan di luar jam kerja, menyediakan fasilitas perumahan, kendaraan, tunjangan kesehatan, dan lainnya. Perusahaan juga selalu mengusahakan lingkungan kerja yang kondusif. Perusahaan menyediakan ruang kerja yang nyaman, memberikan fasilitas sarana dan prasarana penunjang yang layak dan sesuai dengan kebutuhan. Perusahaan juga selalu menciptakan lingkungan kerja yang kondusif baik di dalam perusahaan maupun di luar perusahaan. Perusahaan juga mengirimkan karyawan untuk mengikuti pelatihan. Perusahaan juga memberlakukan sistem reward dan punishment.
\end{abstract}

Kata Kunci : Upaya, Meningkatkan, Produktivitas Kerja, Karyawan.

Setiap perusahaan selalu berusaha agar karyawan bisa berprestasi dalam bentuk memberikan produktivitas kerja yang maksimal. Produktivitas kerja karyawan bagi suatu perusahaan sangatlah penting sebagai alat pengukur keberhasilan dalam menjalankan usaha. Karena semakin tinggi produktivitas kerja karyawan dalam perusahaan, berarti laba perusahaan dan produktivitas akan meningkat. International Labour Organization (ILO) yang dikutip oleh Hasibuan (2005:127) mengungkapkan bahwa "secara lebih sederhana maksud dari produktivitas adalah perbandingan secara ilmu hitung antara jumlah yang dihasilkan dan jumlah setiap sumber yang dipergunakan selama produksi berlangsung. Sumber tersebut dapat berupa: 1) Tanah; 2) Bahan baku dan bahan pembantu; 3) Pabrik, mesin-mesin dan alat-alat; 4) Tenaga kerja". Konsep produktivitas pada dasarnya dapat dilihat dari dua dimensi, yaitu dimensi individu dan dimensi organisasi. Pengkajian masalah produktivitas dari dimensi individu tidak lain melihat produktivitas terutama dalam hubungannya dengan karakteristikkarakteristik kepribadian individu. Dalam konteks ini esensi pengertian produktivitas menurut Kusnendi (2003:84) adalah "sikap mental yang selalu mempunyai pandangan bahwa mutu kehidupan hari ini harus lebih baik dari hari kemarin, dan hari esok harus lebih baik dari hari ini".

Sementara itu ditinjau dari dimensi keorganisasian, menurut Kusnendi (2003:84) “konsep produktivitas secara keseluruhan merupakan dimensi lain dari pada upaya mencapai kualitas dan kuantitas suatu proses kegiatan berkenaan dengan bahasan ilmu ekonomi. Oleh karena itu, selalu berorientasi kepada bagaimana berpikir dan bertindak untuk mendayagunakan sumber masukan agar mendapat keluaran yang optimum. Dengan demikian konsep produktivitas dalam pandangan ini selalu ditempatkan pada kerangka hubungan teknis antara masukan (input) dan keluaran (output)". Menurut Ravianto (1990:68) "produktivitas berhubungan dengan banyaknya masukan dan banyaknya pengeluaran. Produktivitas meningkat bila keluaran tertentu dicapai dengan masukan yang lebih sedikit atau masukan tertentu mengakibatkan keluaran yang lebih besar". Ravianto juaga menyatakan bahwa, "produktivitas dapat meningkat bila barang, material dan mental manusia yang terbuang, menjadi makin sedikit atau sangat terbatas, sehingga lebih banyak porsentase keluaran didapatkan". Masih dalam buku yang sama Ravianto menyatakan bahwa: "Produktivitas tenaga kerja sebagai suatu konsep, menunjukkan adanya kaitan 
antara hasil kerja dengan satuan waktu yang dibutuhkan untuk menghasilkan produk dari seorang tenaga kerja". Produktivitas karyawan bagi perusahaan akan sangat berkontribusi kepada produktivitas perusahaan dan tentunya kenaikan profit perusahaan. Sementara, bagi seorang leader, produktivitas karyawan yang dipimpinnya akan meningkatkan prestasi bagian atau department yang dia pimpin. Meningkatkan produktivitas karyawan tidak cukup dengan terus-menerus mendorong mereka bekerja keras. Ada sebuah set strategi yang perlu diterapkan. Menuntut karyawan untuk bekerja keras bukan solusi yang baik, bahkan bisa menjadi bumerang bagi perusahaan atau leader.

\section{Pemberian Motivasi.}

Perkembangan manajemen menunjukkan bahwa dari sekian banyak teori tentang penggerakan bawahan, teori motivasilah yang banyak digunakan. Kenyataan ini dapat dijelaskan dengan mengatakan bahwa manusia mengaitkan kekaryaannya dengan pemuasan berbagai kebutuhan dan keinginannya, seperti yang terlihat dalam definisi motivasi menurut Siagian (2002:102) yang mengatakan, bahwa motivasi merupakan "Daya dorong bagi seseorang untuk memberikan kontribusi yang sebesar mungkin demi keberhasilan organisasi mencapai tujuannya. Dengan pengertian, bahwa tercapainya tujuan organisasi berarti tercapai pula tujuan pribadi para anggota organisasi yang bersangkutan". Menurut Nitisemito (1989:121) "Motivasi adalah usaha atau kegiatan dari manajer untuk dapat menimbulkan atau meningkatkan semangat atau kegairahan kerja dari para pekerja-pekerja atau karyawankaryawan”. Sedangkan menurut Malayu SP. Hasibuan (2003:95) "Motif adalah suatu perangsang keinginan (want) dan daya penggerak kemauan bekerja seseorang; setiap motif mempunyai tujuan tertentu yang ingin dicapai". Dari tiga definisi tersebut terlihat dengan jelas bahwa organisasi atau perusahaan hanya akan berhasil mencapai tujuan dan berbagai sasarannya, apabila semua komponen organisasi berupaya menampilkan kinerja yang optimal termasuk bagaimana meningkatkan semangat atau kegairahan kerja para karyawan.Agar dapat menimbulkan atau meningkatkan semangat kegairahan kerja maka rahasianya adalah apabila kita mengetahui dengan tepat kebutuhan-kebutuhan para pekerja atau karyawan yang bilamana kita penuhi akan dapat menimbulkan atau meningkatkan kepuasan para pekerja atau para karyawan.

Motivasi berasal dari kata latin "movere" yang berarti dorongan atau daya penggerak. Motivasi mempersoalkan bagaimana dapat memberikan dorongan kepada pengikutnya atau bawahan, agar dapat bekerja semaksimal mungkin atau bekerja bersungguh-sungguh. Menurut Hasibuan (2006:219) bahwa "motivasi adalah pemberian daya pengerak yang menciptakan kegairahan kerja seseorang, agar mereka mau bekerja sama, bekerja efektif dan terintegrasi dengan segala daya upayanya untuk mencapai kepuasan". Motivasi berasal dari kata "motif". Menurut Sardiman (2007:73) mengemukakan bahwa: "kata motif, diartikan sebagai daya upaya yang mendorong seseorang untuk melakukan sesuatu". Motif dapat dikatakan sebagai daya penggerak dari dalam dan didalam sebjek untuk melakukan aktivitas-aktivitas tertentu demi mencapai tujuan. Bahkan motif dapat diartikan sebagai kondisi intern (kesiapsiagaan). Berawal dari kata motif itu, maka motivasi dapat diartikan sebagai daya penggerak yang telah menjadi aktif. Motif menjadi aktif pada saat-saat tertentu, terutama bila kebutuhan untuk menjadi tujuan sangat dirasakan/mendesak. Menurut Moekijat dalam Hasibuan (2006: 218) bahwa "motif adalah suatu pengertian yang mengandung semua alat penggerak alasan-alasan atau dorongandorongan dalam diri manusia yang menyebabkan ia berbuat sesuatu". Hal ini senada dengan Tim Penyusun Kamus Besar Bahasa Indonesia (2008:930), mengartikan motivasi sebagai, "dorongan yang timbul pada diri seseorang secara sadar atau tidak sadar untuk melakukan suatu tindakan dengan tujuan tertentu". Sedangkan Sardiman (2007: 73) mendefinisikan motivasi sebagai berikut: "Motivasi juga dapat dikatakan serangkaian usaha untuk menyediakan kondisikondisi tertentu, sehingga seseorang mau dan ingin 
melakukan sesuatu dan bila ia tidak suka, maka akan berusaha untuk meniadakan atau mengelakkan perasaan tidak suka itu. Jadi motivasi itu dapat dirangsang oleh faktor dari luar tetapi motivasi itu adalah tumbuh didalam diri seseorang". Dengan adanya pemberian motivasi diharapkan karyawan akan bekerja dengan semangat, yang pada akhirnya akan meningkatkan produktivitas kerjanya. Untuk memotivasi karyawan diperlukan kemampuan pimpinan, dalam memenuhi kebutuhan karyawan yang sejalan dengan keinginan perusahaan, sebab jika pimpinan tidak mampu memotivasi karyawan maka produktivitas kerja karyawan akan menurun dan tentu saja akan berpengaruh terhadap produktivitas perusahaan.

\section{Lingkungan Kerja yang Kondusif.}

Banyak hal yang dapat mempengaruhi produktivitas kerja, untuk itu perusahaan harus berusaha menjamin agar faktor yang berkaitan dengan produktivitas dapat dipenuhi secara maksimal, menurut Sinungan (2003:83) "salah satu faktor yang mempengaruhi adalah lingkungan kerja. Kenyamanan lingkungan kerja karyawan dapat memicu karyawan untuk bekerja lebih baik sehingga produktivitas kerja dapat dicapai secara maksimal". Lingkungan kerja yang baik diharapkan dapat memacu produktivitas kerja karyawan yang tinggi. Menurut Davis dan Newstrom (1985:14) bahwa "setiap perusahaan akan menghadapi perubahan lingkungan yang bersifat teknis dan fenomatik". Untuk mendukung tingkat produktivitas kerja karyawan dapat dilakukan dengan menciptakan lingkungan kerja yang menyenangkan, lingkungan kerja merupakan segala sesuatu di sekitar pekerja dan dapat berpengaruh terhadap pekerjanya. Lingkungan kerja yang baik akan sangat besar pengaruhnya terhadap produktivitas kerja karyawan, menurut Nitisemito (1992:192) aspek yang berpengaruh terhadap lingkungan kerja antara lain: "pengaturan penerangan, tingkat kerja, kebisingan, namun penerangan disini diartikan sebagai pengaturan dan sirkulasi udara yang baik terutama didalam lingkungan kerja, kebersihan lingkungan kerja, dan keamanan terhadap barang milik karyawan".
Lingkungan kerja mempunyai pengaruh terhadap kinerja karyawan perusahaan dalam usaha untuk menyelesaikan tugas-tugas yang dibebankan kepadanya yang akhirnya berpengaruh terhadap produktivitas kinerja karyawan, lingkungan yang baik akan meningkatkan kerja, begitupula sebaliknya apabila lingkungan kerja kurang tenang, akan dapat mempertinggi tingkat kesalahan yang mereka lakukan. Sebuah perusahaan yang beroperasi di sebuah lingkungan tidak dapat menafikan bahwa selain kegiatan bisnis mereka juga terlibat dengan lingkungan disekitar perusahaan, oleh karena itu setiap perusahaan perlu memahami secara mendalam mengenai lingkungan apa saja yang terkait secara langsung maupun tidak langsung dengan kegiatan kerjanya. Adapun pengertian lingkungan kerja, menurut Sinungan (2003:16) adalah "sikap mental yang selalu mempunyai pandangan bahwa mutu kehidupan hari ini lebih baik daripada hari kemarin, esok lebih baik dari hari ini".

Lingkungan yang mendukung akan dapat mendorong karyawan untuk bekerja lebih baik dan bersungguh-sungguh sehingga produktivitas kerja yang maksimal dapat dicapai.sesuai dengan teori bisnis, harus ada kesesuaian antara asumsi lingkungan yang akan di hadapi dengan visi dan misi yang diemban serta kemampuan utama yang dimiliki agar visi perusahaan dapat menjadi kenyataan dan tidak hanya sekedar menjadi mimpi belaka. Lingkungan dalam sebuah pekerjaan (task environment) mencakup elemen-elemen atau kelompok- kelompok yang tindakan maupun keinginannya mempengaruhi perusahaan secara langsung. Mereka yang mempunyai kepentingan adalah para pemegang saham, supplier, pesaing, pelanggan, kreditur, serikat pekerja, dan asosiasi dagang seperti kadin dan pemerintah, menurut Hariadi (2005:46) "lingkungan kerja mencakup berbagai aspek penekan umum yang tidak secara langsung mempengaruhi aktivitas perusahaan dalam jangka waktu pendek, tetapi dapat mempengaruhi keputusan jangka panjang perusahaan sehingga hal ini dapat mengganggu kegiatan operasional perusahaan". 
Besarnya pengaruh lingkungan kerja terhadap setiap perusahaan tentu akan berbedabeda, tetapi perusahaan yang dapat berkembang dengan baik, pada umumnya adalah perusahaan yang selalu melakukan inovasi tiada henti misalnya yang dilakukan oleh sejumlah perusahaan di Indonesia diantaranya : Astra, aqua, pabrik rokok jarum, inovasi atau mati. Banyak perusahaan yang bangkrut karena gagal menyesuaikan diri dengan perubahan lingkungan atau lebih buruk lagi adalah kegagalan perubahan, tidak ada yang tetap kecuali perubahan tersebut. Perusahan yang inovatif adalah mereka yang selalu menyesuaikan diri dengan lingkungan yang dihadapi. Menurut Swastha (1999:31) ada dua lingkungan utama yang menjadi bahan pertimbangan dalam menyusun strategi, yaitu: “(1) perubahan lingkungan ekstern perusahaan yang mencakup lingkungan pekerjaan atau industri dan lingkungan sosial (2) perubahan lingkungan intern perusahaan, lingkungan perusahaan mencakup elemen penting atau kelompok, yang tindakan maupun keinginannya mempengaruhi perusahan secara langsung". Menurut Hariadi (2005:46) "Mereka yang punya kepentingan adalah: pemegang saham, suplier, kreditur, pesaing, pelanggan, serikat pekerja dan asosiasi dagang seperti kadin dan pemerintah".

Menurut Steers M. Richard dalam Magdalena (1980:123) "Lingkungan kerja juga dapat diartikan sebagai sikap, nilai, norma, dan perasaan yang lazim dimiliki oleh para karyawan sehubungan dengan organisasi mereka". Dengan kata lain lingkungan kerja dianggap sebagai kepribadian suatu perusahaan seperti yang dilihat oleh para pekerjanya, jika para karyawan merasa lingkungannya terlalu otoriter maka dapat diduga bahwa mereka akan bertindak sesuai dengan anggapan ini, sekalipun pihak menejer melakukan segala usaha untuk bersikap demokratis atau mementingkan karyawan. Perbaikan di lingkungan kerja itu sendiri dapat menumbuhkan kegairahan semangat dan kecepatan kerja, demikian juga perbaikan di bidang pengupahan dan jaminan sosial dapat menumbuhkan motivasi kerja sehingga produktivitas yang di hasilkan juga lebih baik. Lingkungan kerja menurut Nitiseminto (2002:27) "adalah segala sesuatu yang ada di sekitar para pekerja dan yang dapat mempengaruhi dirinya dalam menjalankan tugas-tugas yang di bebankan kepadanya". Sebuah perusahaan atau organisasi bisnis yang beroperasi di sebuah lingkungan tidak dapat menafikan bahwa, selain kegiatan bisnis yang di kelolanya, mereka tersebut juga terlibat di lingkungan seputar organisasi, oleh karena itu sebuah perusahaan perlu memahami lingkungan apa saja yang terkait langsung maupun tidak langsung dalam kegiatan perusahaan. Setiap perusahaan pasti mengharapkan suatu lingkungan kerja yang selalu bersih, rapi, dan masing-masing orang mempunyai konsistensi dan disiplin diri, sehingga mampu mendukung terciptanya tingkat efisiensi dan produktivitas yang tinggi di perusahaan. Lingkungan kerja menunjuk pada halhal yang berada di sekeliling dan melingkupi kerja karyawan. Kondisi ini lebih banyak tergantung pimpinan, sehingga suasana kerja yang tercipta tergantung pada pola yang diciptakan pimpinan.

\section{Pelatihan Karyawan.}

Pada dasarnya tujuan pelatihan yaitu ingin mengembangkan karyawan untuk terampil, terdidik, dan terlatih secara profesional dan siap pakai dalam bidangnya masing-masing. Pelatihan berhubungan dengan menambah pengetahuan keterampilan dan kecakapan untuk melakukan pekerjaan tertentu. Istilah pelatihan ini digunakan untuk menunjukkan setiap proses keterampilan atau kecakapan dan kemampuan para pegawai, sehingga mereka lebih baik menyesuaikan dengan lingkungan kerja yang mereka geluti. Selanjutnya pengertian pelatihan secara sederhana didefinisikan oleh Pramudyo (2007:16) sebagai : "Proses pembelajaran yang dirancang untuk mengubah kinerja orang dalam melakukan pekerjaannya". Yang dimaksud dalam hal ini adalah adanya empat hal yang harus diperhatikan. Yaitu proses pelatihan, kinerja, peserta pelatihan, dan pekerjaan. Harus dipahami bahwa proses pelatihan mengacu kepada suatu perubahan yang harus terjadi pada peserta pelatihan. Dalam proses pelatihan, kinerja yang kurang baik dibenahi sedemikian rupa sehingga menjadi lebih baik. Sehingga sekumpulan tugas- 
tugas yang telah menanti dapat dikerjakan dengan baik oleh pekerja yang telah mengikuti pelatihan. Menurut Gary Dessler (2006:280) bahwa: "Pelatihan merupakan proses mengajar ketrampilan yang dibutuhkan karyawan untuk melakukan pekerjaannya".

Dari uraian tersebut di atas mencerminkan manfaatnya sangat penting dari pelaksanaan pelatihan dalam upaya meningkatkan produktivitas kayrawan yang sekaligus akan berpengaruh terhadap produktivitas karyawan. Dengan pelaksanaan pelatihan terdapat manfaat lain bagi perusahaan dalam melaksanakan aktivitasnya yaitu agar lebih menjamin tersedianya tenaga-tenaga terampil dalam perusahaan, sehingga kesalahankesalahan dapat dihindari serta mendorong karyawan untuk memberikan potensi yang dimilikinya untuk waktu yang lama. Pelatihan sumber daya manusia merupakan salah satu topik yang sangat penting dalam rangka manajemen sumber daya manusia. Pelatihan adalah salah satu aspek penting dalam usaha meningkatkan keunggulan bersaing organisasi perusahaan. Adanya perubahan-perubahan lingkungan bisnis, lingkungan kerja, menghendaki perusahaan harus melakukan pelatihan sumber daya manusianya secara proaktif, demi mencapai produktivitas kerja yang lebih baik.

\section{Reward dan Punishment.}

Reward dan punishment merupakan dua bentuk metode dalam memotivasi seseorang untuk melakukan kebaikan dan meningkatkan prestasinya. Kedua metode ini sudah cukup lama dikenal dalam dunia kerja. Tidak hanya dalam dunia kerja, dalam dunia penidikan pun kedua ini kerap kali digunakan. Namun selalu terjadi perbedaan pandangan, mana yang lebih diprioritaskan antara reward dengan punishment. Reward artinya ganjaran, hadiah, penghargaan atau imbalan. Dalam konsep manajemen, reward merupakan salah satu alat untuk peningkatan motivasi para pegawai. Metode ini bisa mengasosiasi-kan perbuatan dan kelakuan seseorang dengan perasaan bahagia, senang, dan biasanya akan membuat mereka melakukan suatu perbuatan yang baik secara berulang-ulang. Selain motivasi, reward juga bertujuan agar seseorang menjadi giat lagi usahanya untuk memperbaiki atau meningkatkan prestasi yang telah dapat dicapainya. Sementara punishment diartikan sebagai hukuman atau sanksi. Jika reward merupakan bentuk reinforcement yang positif; maka punishment sebagai bentuk reinforcement yang negatif, tetapi kalau diberikan secara tepat dan bijak bisa menjadi alat motivasi. Tujuan dari metode ini adalah menimbulkan rasa tidak senang pada seseorang supaya mereka jangan membuat sesuatu yang jahat. Jadi, hukuman yang dilakukan mesti bersifat pedagogies, yaitu untuk memperbaiki dan mendidik ke arah yang lebih baik. Pada dasarnya keduanya sama-sama dibutuhkan dalam memotivasi seseorang, termasuk dalam memotivasi para pegawai dalam meningkatkan kinerjanya. Keduanya merupakan reaksi dari seorang pimpinan terhadap kinerja dan produktivitas yang telah ditunjukkan oleh bawahannya; hukuman untuk perbuatan jahat dan ganjaran untuk perbuatan baik. Melihat dari fungsinya itu, seolah keduanya berlawanan, tetapi pada hakekatnya sama-sama bertujuan agar seseorang menjadi lebih baik, termasuk dalam memotivasi para pegawai dalam bekerja.

Menurut Nugroho (2006:5) "Reward adalah ganjaran, hadiah, penghargaan atau imbalan yang bertujuan agar seseorang menjadi lebih giat lagi usahanya untuk memperbaiki atau meningkatkan kinerja yang telah dicapai". Menurut Simamora (2004:514) "reward adalah insentif yang mengaitkan bayaran atas dasar untuk dapat meningkatkan produktivitas para karyawan guna mencapai keunggulan yang kompetitif'. Dengan adanya pendapat para ahli diatas maka dapat disimpulkan bahwa pemberian reward dimaksudkan sebagai dorongan agar karyawan mau bekerja dengan lebih baik sehingga dapat meningkatkan kinerja karyawan. Menurut Mangkunegara (2000:130) "punishment adalah ancaman hukuman yang bertujuan untuk memperbaiki kinerja karyawan pelanggar, 
memelihara peraturan yang berlaku dan memberikan pelajaran kepada pelanggar". Menurut Ivancevich, Konopaske dan Matteson dalam Gania (2006:226) "punishment didefinisikan sebagai tindakan menyajikan konsekuensi yang tidak menyenangkan atau tidak diinginkan sebagai hasil dari dilakukanya perilaku tertentu".

\section{METODE PENELITIAN}

Jenis penelitian adalah sesuatu yang dapat diartikan sebagai Mengatur latar (Setting) penelitian agar memperoleh data yang tepat (Vallid) sesuai dengan karakteristik variabel dan tujuan penelitian. Menurut Campbell dan Stanley dalam Moleong (2000:236) "Jenis penelitian (Research Design) adalah tahap perlakuan sebelum dan sesudah eksperimen". Sedangkan menurut Chrism dalam Moleong (2000:236) "Memandang sebagai tahaptahap pelaksanaan data". Lokasi penelitian pada PT. Perdana Sawit Plantation Kecamatan Ketungau Tengah.

\section{HASIL PENELITIAN DAN PEMBAHASAN Pemberian Motivasi.}

Pemberian motivasi yang dilakukan oleh pimpinan pada PT. Perdana Sawit Plantation sudah berjalan cukup baik, hal ini dapat dilihat dari kinerja karyawan yang cukup baik, dimana pekerjaan-pekerjaan yang menjadi tanggung jawab karyawan dapat diselesaikan sesuai dengan tenggat waktu yang diberikan. Pemberian motivasi dilakukan oleh pimpinan perusahaan di lapangan, dan khusus untuk karyawan harian dilakukan oleh mandor di masing-masing kelompok kerja. Perusahaan sangat menyadari bahwa keberadaan karyawan merupakan faktor yang sangat penting dalam sebuah perusahaan, maka dengan demikian perusahaan selalu berupaya untuk mendorong dan memotivasi karyawan untuk bekerja dengan sebaikbaiknya dan berdisiplin tinggi, sehingga kinerja karyawan akan meningkat yang pada akhirnya akan meningkatkan produktivitas perusahaan. Motivasi mempersoalkan bagaimana caranya mendorong gairah kerja bawahan, agar mereka mau bekerja keras dengan memberikan semua kemampuan dan ketrampilannya untuk mewujudkan tujuan perusahaan. Pada dasarnya perusahaan bukan saja mengharapkan karyawan yang mampu, cakap dan terampil, tetapi yang terpenting mereka mau bekerja giat dan berkeinginan untuk mencapai hasil kerja yang optimal.

Sumber Daya Manusia merupakan salah satu faktor yang dibutuhkan perusahaan untuk melaksanakan kegiatan atau aktivitas perusahaan guna mencapai tujuannya. Persaingan mengakibatkan perusahaan dituntut untuk mampu bertahan dan semakin dapat memacu dirinya untuk berkembang, namun disisi lain tidak sedikit pula perusahaan-perusahaan yang jatuh karena tidak mampu bersaing dengan perusahaan lain. Di samping mampu bertahan dan mengembangkan dirinya, pada dasarnya setiap perusahaan senantiasa berusaha untuk mendapatkan keuntungan yang optimal dengan jumlah pengorbanan yang dikeluarkan perusahaan, ini berarti perusahaan akan selalu berusaha untuk bekerja secara efektif dan efisien dalam memanfaatkan sumber daya yang dimiliki baik sumber daya alam, modal maupun sumber daya manusia. Apabila perusahaan mampu memberikan atau meningkatkan motivasi kerja karyawan, maka perusahaan akan lebih cepat dalam menyelesaikan tugas-tugasnya, kerusakan-kerusakan akan dapat dikurangi, pemborosan-pemborosan dapat diminimalkan, absensi karyawan dapat diperkecil, kemungkinan perpindahan karyawan dapat diperkecil, sehingga dapat diharapkan bukan saja produktifitas kerja dapat ditingkatkan tetapi juga efisiensi. Sebaliknya jika motivasi kerja karyawan menurun berarti perusahaan akan banyak mengalami kerugian.

Oleh karena itu perusahaan harus dapat mengetahui indikasi turunnya motivasi karyawan sehingga perusahaan akan dapat mengambil tindakan pencegahan atau pemecahan sedini mungkin. Untuk dapat mengetahui indikasi menurunnya motivasi kerja karyawan tidaklah mudah. Perusahaan harus meneliti kebenaran sebelum mengambil keputusan. Meskipun demikian sebelum mengambil keputusan sebaiknya diadakan 
penelitian terlebih dahulu sebab-sebab indikasi tersebut. Organisasi perusahaan adalah suatu kesatuan yang saling berhubungan antara satu dengan yang lainnya didalam tubuh organisasi, apabila terjadi kekeliruan akan menyebabkan hambatan yang serius. Untuk menghindari yang mungkin dapat terjadi, hendaknya para karyawan diberikan motivasi secara terus menerus, baik karyawan yang lama maupun yang baru. Sementara itu ada hal-hal yang menyebabkan ketidak stabilan perusahaan, antara lain pemberian motivasi yang kurang terarah pada karyawan, ini bisa dibuktikan dengan rendahnya produktivitas kerja, tingkat absensi yang tinggi, banyak karyawan yang pindah ke perusahaan lain, sementara itu target perusahaan tidak tercapai. Jadi disini jelas bahwa, motivasi kerja sangat diperlukan sebelum atau waktu menjalankan aktivitas kerja tersebut. Karena tanpa adanya motivasi kerja pada diri seseorang, kemungkinan hasil yang dicapai kurang memuaskan.

\section{Lingkungan Kerja yang Kondusif.}

Peningkatan produktivitas perusahaan tersebut tidak lepas dari adanya faktor yang mempengaruhi salah satunya adalah faktor lingkungan hal ini sejalan dengan teorinya para ahli yang menyatakan bahwa lingkungan kerja berpengaruh terhadap produktivitas karyawan. Oleh karena itu perusahaan harus memperhatikan kondisi lingkungan tempat bekerja mulai dari ventilasi udara, keamanan dan kebersihan tempat kerja, lingkungan yang bersih akan mengakibatkan karyawan akan semangat dalam bekerja karena setengah dalam sehari waktu mereka dihabiskan dalam lingkungan kerja tersebut. Lingkungan yang mendukung akan dapat mendorong karyawan untuk bekerja lebih baik sehingga produktivitas kerja yang maksimal dapat dicapai. Lingkungan kerja adalah semua keadaan tempat kerja dapat mempengaruhi pegawai atau karyawan baik secara langsung maupun tidak langsung selain itu lingkungan kerja merupakan suatu komunitas manusia berkumpul dalam suatu keberagaman serta dalam situasi dan kondisi yang berubah-ubah yang dapat mempengaruhi kinerja karyawan sehingga produk yang dihasilkan kurang efektif dan hal ini berarti produktivitas karyawan semakin menurun.

\section{Pelatihan Karyawan.}

Pelatihan merupakan cara yang digunakan oleh setiap perusahaan dalam mengembangkan skill and knowledge bagi para karyawannya. Hal ini dilakukan perusahaan agar para karyawan dapat saling bahu-membahu dalam mencapai tujuan perusahaan. Sehingga pelatihan yang perusahaan wajibkan kepada para pekerjanya akan efisien. Setiap pelatihan yang dilaksanakan memiliki beragam materi yang tersaji sesuai dengan kebutuhan. Model pelatihan yang diprioritaskan oleh perusahaan bagi pekerjanya, harus disesuaikan dengan tujuan akhir dari pelatihan tersebut. Sehingga pelatihan yang dilaksanakan akan efisien dan efektif. Setiap pekerja memiliki kekuatan dan kelemahan, hal ini adalah manusiawi mengingat manusia tidak ada yang sempurnah. Sehingga perusahaan harus pintar menyeleksi dan memonitor mengenai metode-metode apa yang sesuai dengan tingkat kemampuan pekerja, perusahaan harus bisa melihat hal-hal apa saja yang dibutuhkan pekerja agar dapat meningkatkan skill and knowledge mereka. Karena tingkatan usia para pekerja yang menjadi peserta pelatihan pasti berbeda. Dan hal ini adalah salah satu faktor bagaimana mereka menangkap materi yang diberikan kepada mereka.

\section{Reward dan Punishment.}

Masalah sumberdaya manusia masih menjadi sorotan utama bagi perusahaan untuk tetap dapat bertahan di era globalisasi. Sumber daya manusia mempunyai peran utama dalam setiap kegiatan perusahaan. Walaupun didukung dengan sarana dan prasarana serta sumber daya alam yang memadai, tetapi tanpa dukungan sumberdaya manusia yang handal kegiatan perusahaan tidak akan terselesaikan dengan baik. Hal ini menunjukan bahwa sumber daya manusia merupakan kunci pokok yang harus diperhatikan dengan segala kebutuhanya. Sebagai kunci pokok, sumber daya manusia akan menentukan keberhasilan 
pelaksanaan kegiatan perusahaan. Tuntutan perusahaan untuk memperoleh, mengembangkan dan mempertahankan sumber daya manusia semakin mendesak sesuai dengan dinamika lingkungan yang selalu berubah. Pentingnya peranan sumber daya manusia tercermin dari kebutuhan perusahaan untuk membuat strategi manajemen sumber daya manusia sejajar dengan pentingnya strategi di bidang lainya. Manajemen sumber daya manusia merupakan program, aktivitas untuk mendapatkan, mengembangkan, memelihara dan mendayagunakan sumber daya manusia untuk mendukung perusahaan mencapai tujuannya. Dalam mencapai tujuan perusahaan, dibutuhkan sumber daya manusia (karyawan) yang berkualitas. Kualitas atau kinerja karyawan harus selaludipelihara dan ditingkatkan,salah satu caranya adalah dengan penerapan reward dan punishment. Perusahaan menyadari demi menjaga dan meningkatkan kinerja karyawan perusahaan harus segera berbenah dalam pengelolaan manajemen yang profitable dan professional, salah satu caranya adalah dengan menerapkan reward dan punishment. Diharapkan dengan adanya

\section{DAFTAR PUSTAKA}

Hariadi. B. 2005. Strategi Menejemen. Malang: Bayumedia Publishing

Hasibuan, Melayu S.P. 2003. Organisasi dan motivasi; dasar peningkatan produktivitas. Cetakan ke empat. Jakarta : PT. Bumi Aksara.

2005. Manajemen SDM. Edisi Revisi, Cetakan Ke Tujuh. Jakarta : Bumi Aksara. 2006. Manajemen Sumber Daya Manusia. Jakarta: PT Bumi Aksara.

Magdalena. 1980. Efektivitas Organisasi.

Jakarta: Penerbit Erlangga,

Nitisemito, C. Alex S.1989. Manajemen Suatu Dasar dan Pengantar. Edisi Revisi Dua. Cetakan ketiga. Jakarta : Ghalia Indonesia. 2002. Manajemen Personalia. Jakarta: Penerbit Erlangga. penerapan reward dan punishment kinerja karyawan dapat ditingkatkan dan perusahaan dapat mencapai tujuanya secara keseluruhan.

\section{KESIMPULAN DAN SARAN}

Untuk meningkatkan produktivitas kerja karyawan, pimpinan perusahaan sudah memberikan motivasi kepada para karyawan untuk bekerja dengan baik, penuh semangat, dan berdisiplin. Perusahaan juga selalu mengusahakan lingkungan kerja yang kondusif, sehingga memberikan rasa nyaman kepada para karyawan dalam bekerja. Perusahaan juga mengirimkan karyawan untuk mengikuti pelatihan. perusahaan juga memberlakukan sistem reward dan punishment. Peneliti menyarankan beberapa hal sebagai berikut: Upaya-upaya peningkatan produktivitas kerja karyawan yang sudah dilakukan agar terus ditingkatkan, sehingga produktivitas karyawa tetap terjaga. Lingkungan kerja yang kondusif terutama terciptanya hubungan yang baik dengan masyarakat sekitar tetap harus terus terjaga, sehingga memberikan rasa nyaman kepada perusahaan untuk berusaha.

2004. Wawasan Studi Kelanyakan Dan Evaluasi Proyek. Jakarta: Bumi Aksara,

Nugroho. B. 2006. Reward dan Punishment. Bulletin cipta karya, departemen pekerjaan umum edisi no 6/IV/ juni 2006.

Ravianto. 1990. Produktivitas dan Teknologi.

Saksono. J. 1990. Produktivitas dan Teknologi Seri Produktivitas kelima, cetakan

Siagian, Sondang P. 2002. Kiat meningkatkan Produktivitas Kerja. Cetakan Pertama. Jakarta : Rineka Cipta.

Sinungan, M. 2000. Produktivitas Apa dan Bagaimana. Edisi dua. Cetakan Keempat. Jakarta : Bumi Aksara. Produktivitas Apa Dan Bagaimana. Jakarta: Bumi Aksara.

Swastha. B. 1999. Pengantar Bisnis Moderen. Yogyakarta: Liberty. 